\title{
PATUNG TAU TAU DI TORAJA PROVINSI SULAWESI SULAWESI SELATAN: Kajian Simbol Susanne Knauth Langer
}

\author{
Suherman \\ Pascasajana, Universitas Negeri Semarang \\ suhermankasumba@gmail.com
}

\begin{abstract}
Abstrak
Patung Tau Tau di Toraja, Sulawesi Selatan merupakan salah satu karya seni yang tergolong dalam karya seni ritual. PatungTau Tau adalah replika dari masyarakat Toraja yang meninggal dunia.Patung Tau Tau sebagai karya seni ritual, oleh karena Patung Таи Tau erat kaitannya dengan proses ritual keagamaan. Dalam kepercayaan suku adat Toraja (Aluk Todolo), Tau Tau bukan melambangkan badan atau raga almarhum, melainkan simbol roh atau spirit sang almarhum yang tidak ikut mati, tetapi melanjutkan kehidupan lain di alam berikutnya sesudah kematian. Kehadiran seni dalam ritual agama, menjadi satu kesatuan yang akrab, sebagaimana kegiatan itu disamping pengalaman keimanan, sekaligus juga pengalaman estetis. Berdasarkan pemahaman bahwa manusia berfikir, berperasaan, dan bersikap dalam ungkapan-ungkapan simbolis,sebagaimana Susanne Knauth Langer (1895-1985) yang pernah menjadi murid Ernest Cassirer, bahwa simbolisme merupakan ciri khas bagi manusia yang dengan terang membedakannya dengan hewan.
\end{abstract}

Kata Kunci: Toraja, Patung Tau Tau, Susanne Knauth Langer, Simbol

\section{TAU TAU STATUE IN PROVENCE TORAJA SOUTH SULAWESI: Susane Knauth Langer's Study of Symbols}

\begin{abstract}
The statue ofTauSouth Tau in Toraja, Sulawesi is a kind of art work which is categorized into ritual art.Tau Tau is a replica of dead people in Toraja. It is considered ritual art work because this statue is closely related to ritual process in Toraja. In one of the Toraja beliefs (Aluk Todolo), Tau Tau does not symbolyze the dead body, but the spirit of the dead, which continue to live in another world.Art in religious rituals is one close entity as the formation of religious as well as aesthetic experience.Based on the understanding that human beings think, feel, and have certain attitudes in symbolic expressions, Susanne Knauth Langer (1895-1985), who once became the student of Ernest Cassirer, thinks that simbolism is a special characteristis that human beings have, which then differenciate them from animals.
\end{abstract}

Keywords: Toraja, Tau Taustatue, Susanne Knauth Langer, symbol 


\section{PENDAHULUAN}

Suku Toraja merupakan salah satu suku yang menghuni daratan Sulawesi Selatan.Sejak dahulu, suku Toraja telah memeluk kepercayaan yang disebut Aluk Todolo.Aluk dapat diartikan sebagai aturan atau upacara, sementara Todolo artinya leluhur atau nenek moyang. Ajaran Aluk Todolo mengemukakan bahwa di luar diri manusia terdapat tiga kekuatan yang wajib dipercayai akan kebenaran, kebebasan, dan kekuasaan. Ketiga kekuatan yang dimaksudadalah pertama Puang Matua, yakni unsur kekuatan yang paling tinggi; kedua Daeta-daeta, yakni unsur kekuatan yang diturunkan oleh Puang Matua kepada manusia pertama, yang kemudian deberikan kekuasaan dan tanggung jawab agar seluruh isi bumi dapat digunakan dan didiami oleh manusia untuk menyembah kepada Puang Matua; kemudian, yang ketiga adalah Tomebali Puang, yakni unsur kekuatan yang juga disebut Todolo, merupakan penjelmaan para leluhur yang kemudian menjadi dewa (Said, 2004:26-27).

Dalam budaya suku adat masyarakat Toraja (secara umum), ritual kematian yang dikenal dengan istilah Aluk Rambu Solo', Aluk= Keyakinan atau aturan, Rambu= Asap dan Solo'= Turun (Sitonda, 2007:47). Berdasarkan makna dari ketiga kata, yang kemudian menjadi Aluk Rambu Solo', dapat diartika sebagai upacara yang dialaksanakan pada waktu sinar matahari terbenam atau turun.Pada upacara kematian yang dilaksanakan oleh sebagian masyarakat Toraja, dengan sebutan Aluk Rambu Solo ’ini, merupakan suatu keyakinan yang dianut oleh masyarakat Toraja. Keyakinan yang dimaksud, adalah apa yang disebut Aluk Todolo--paham animisme sebelum agama Kristen, Katolik dan Islam masuk--, yakni kepercayaan dan pemujaan kepada arwah leluhur (Sitonda, 2007:48-49).

Edward Burnett Taylor (1832-1917) dalam bukunya,Primitive culture, mencoba menyusun kembali asal dan evolusi pengalaman-pengalaman dan kepercayaan-kepercayaan religius. Menurut Taylor, tahap awal agama ialah kepercayaan animisme: kepercayaan bahwa alam mempunyai jiwa. Kepercayaan ini fundamental dan universal serta bisa menerangkan pemujaan terhadap orang mati, pemujaan terhadap leluhur atau nenek moyang dan juga menjelaskan asal mula para dewa (Susanto, 1987:22).Hal ini, oleh masyarakat Toraja mencakup seluruh aspek kehidupan manusia, termasuk pemujaan atas arwah para leluhur.Menurut kepercayaan Aluk Todolo, bahwa orang meninggal hanyalah 
suatu perubahan status semata-mata, dari manusia yang hidup menjadi roh di alam gaib (Said, 2004:39).

Adapun mengenai kebudayaan tradisional masyarakat suku adat Toraja, yakni ritual kematian, merupakan peristiwa sosial penting yang dihadiri oleh banyak orang dan berlangsung selama beberapa hari serta menjadi salah satu kebudayaan yang kaya akan unsur-unsur seni di dalamnya, baik seni rupa, seni musik, maupun seni tari. Demikian, sebab seni merupakan salah satu unsur dari kebudayaan. Sehubungan dengan hal ini, seni atau kesenian sebagai unsur kebudayaan, yakni suatu benda, produk dari manusia, tetapi lebih dipandang sebagai suatu simbol, lambang, yaitu "mengatakan sesuatu tentang sesuatu", jadi berhadapan dengan makna pesan untuk diresapkan (Hadi, 2006:25). Seni sebagai simbolisasi manusia, sebagimana, prinsip penciptaan seni merupakan pembentukan simbol, dan pembentukan simbol bersifat abstraksi (Langer, 1957: 163).

Seni prasejarah dan seni klasik Indonesia, demikian pula seni di daerah-daerah lain yang sejenis atau setingkat, hampir tidak luput dari isian sombol-simbol yang banyak diantaranya memiliki makna yang sangat dalam (Soedarso, 2006:37).Salah satu diantaranya, yaitu patung Tau Tau, yang oleh masyarakat setempat dinamakan Ma' Tau Tau, yang dipuja melalui pemberian korban persembahan binatang serta tarian tertentu. $M a$, Tau Tau yang dimaksud adalah pembuatan patung untuk warga atau masyarakat yang meninggal dunia.

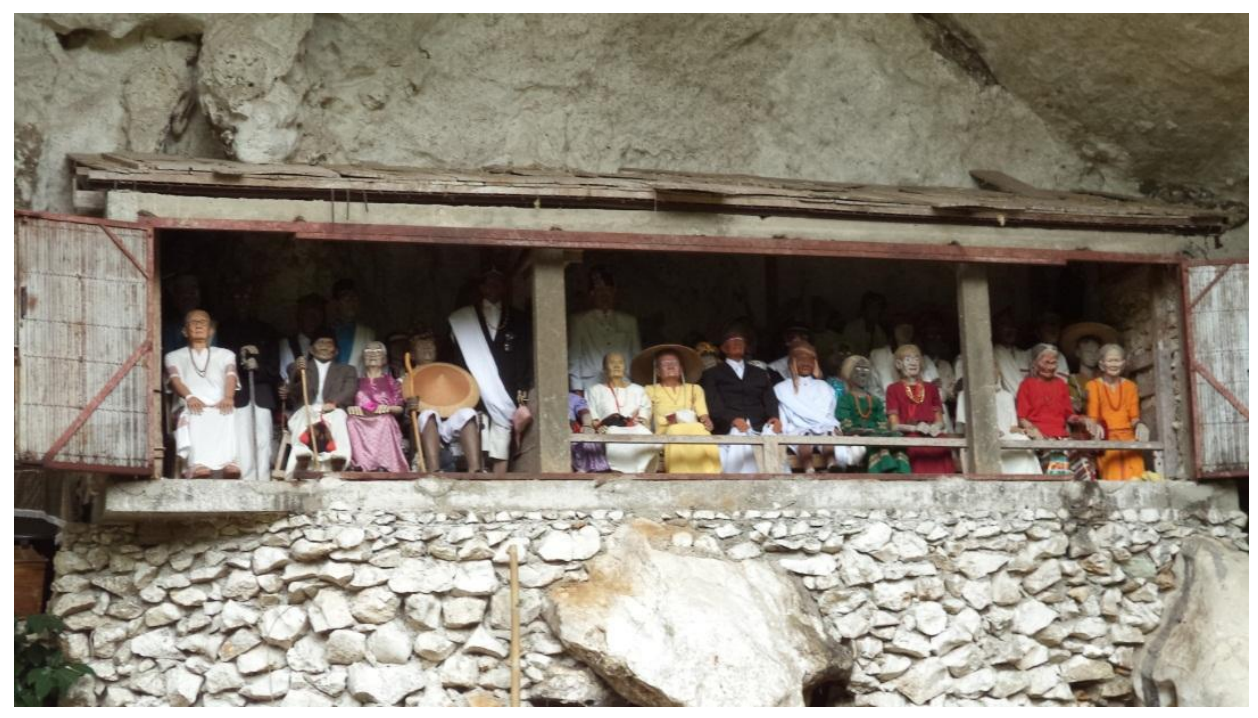

Patung Tau Tau di desa Kete Kesu, Toraja 
Patung Tau Tau adalah replika atau tiruan dari orang Toraja yang sudah meninggal. Biasanya diletakkan di sekitar tempat jenasahnya dimakamkan. Berasal dari kata Tau yang berarti orang atau manusia, dan disertai pengulanganTau yang bermakna menyerupai, Tau Tau secara harafiah berarti orang-orangan.Dalam kepercayaan Aluk Todolo. Tau Tau bukan melambangkan badan atau raga almarhum, melainkan simbol roh atau spirit sang almarhum yang tidak ikut mati, tetapi melanjutkan kehidupan lain di alam berikutnya sesudah kematian (http://www.pengetahuan-oemum.com: patung-tau-tau, 2016).

Patung Tau Tau, dibuat semirip mungkin dengan orang yang sudah meninggal. DahuluTau Таи hanya berupa "boneka" kayu dan asal diberi mata, hidung dan mulut, kemudian diberi pakaian. Tetapi seiring perkembangan zaman, kini sudah banyak pengrajin Tau Tau yang ahli membuatnya hampir sama persis dengan orang yang sudah meninggal tersebut. Tau Tau dianggap suci, kalau dibuat berdasarkan ritual masyarakat setempat dengan melakukan pemotongan babi, tidak boleh dipajang/dipamerkan di muka umum, dan pembuatannya dilakukan di rumah si pengrajin. Kalau sudah ditempatkan di depan kubur, tidak ada yang boleh menyentuh Таи Tau kecuali saat upacara menghubungi leluhur. Kadang, Таи Tau ditempatkan di tempat khusus yang terkunci untuk menghindari orangorang yang berniat jahat mengambilnya. Konon Tau Tau hasil curian dari makam berharga jauh lebih mahal, diperjual belikan dengan sembunyi-sembunyi dan selalu ada orang pembeli yang memburunya (http://wandaseptianibulo: ritual-kematian-dan-kepercayaan, 2016).

\section{PEMBAHASAN}

Patung Tаи Tau di Toraja merupakan suatu karya seni adiluhung yang telah ada sejak masyarakat suku adat Toraja masih menganut paham animisme, hingga saat ini (modern), dan juga merupakan salah satu karya seni dengan nilai-nilai keindahan yang terkandung di dalamnya,yang kemudian ditampilkan melalui simbo-simbol. Sebagaimana diketahui bahwa Patung Tau Tau di Toraja merupakan suatu proses ritual pada upacara kematian, dimana dalam kepercayaan Aluk Todolo, warga atau masyarakat yang meninggal dunia dibuatkan patung "replika" yang oleh masyarakat suku adat Toraja disebutnya Ma' TauTau, 
yakni pemujaan terhadap roh para leluhur. Sebagaimana, menurut kepercayaan Aluk Todolo, pembuatan Patung Tаи Tau ini bukan hanya sekedar melambangkan badan atau raga almarhum, melainkan simbol roh atau spirit sang almarhum yang tidak ikut mati. Dalam hal ini, Patung Tau Tau di Toraja merupakan suatu karya seni dalam konteks seni dalam proses ritual agama (Seni Ritual).

Jakob Sumardjo (2010:111), dalam bukunyaEstetika Paradoks, menguraikan tentang "Seni Ritual", dimana seni mengandung spiritualitas yang ditangkap seniman atau peseninya dalam wujud-wujud analogi, karena "yang tak ada" itu sulit dirumuskan dalam “ada" (budaya). Di sini, mengacu pada konsep dan pengalaman budaya, namun, bukan hanya sekedar itu, tetapi juga wujud kehadiran yang spiritual itu.Sementara, yang spiritual itu realitas transenden dari wilayah "kosong", yang kemudian hanya terasa ada dan hadir dalam simbol-simbolnya saja.Simbol itu sendiri adalah realitas transenden.Kehadirannya hanya terjadi dalam peristiwa ritual dalam ruang dan waktu "kesekarangan" alias "keabadian".

Lebih lanjut, Sumardjo menyatakan bahwa dalam budaya pra-modern pengalaman seni merupakan pengalaman dengan daya-daya transenden yang dipercayainya.Daya-daya spiritual hadir dalam wujud medium simbol -simbol seni. Yang transenden berasal dari luar pengalaman budaya, maka wujud seninya juga bukan berasal dari budayanya.Manun, melalui pengalaman budayalah, yang transenden dapat dipahami.Seni upacara menghasilkan wujud paradoks antara yang dikenal, dan yang tidak diketahui dalam budaya suku, agar yang transenden dapat dipahami.Yang Ilahiah hadir dalam dunia manusia melalui transformaasi budaya suku.Transformasi ini adalah kreativitas, dimana membuat yang tidak dikenal dalam budaya menjadi dapat dikenal (Sumardjo, 2010:115).

Kemudian, beranjak dari apa yang pernah dikatakan oleh Herbert Read (1970:44-64), bahwa ketika agama berbicara masalah unsur-unsur ritualnya, maka di situ nampak erat berkaitan dengan seni. Kehadiran seni dalam ritual agama, menjadi satu kesatuan yang akrab, sebagaimana kegiatan itu disamping pengalaman keimanan, sekaligus juga pengalaman estetis.Kegiatan-kegiatan semacam ini dapat dilihat dalam pola-pola 
kepercayaan mitos dengan jenis-jenis ritus magi, yang didalamnya mengandung kekuatan yang menghubungkan kehendak manusia dengan penguasanya, roh-roh nenek moyang, ataupun menyiasati perjalanan alam, dan mempengaruhi kekuatan lainnya (Hadi, 2006:297298). Sekiranya, inilah yang kemudian ditampilkan oleh masyarakat suku adat Toraja dalam proses ritual pada upacara kematian, yang hingga saat ini masih sering dijumpai di Toraja provinsi Sulawesi Selatan, dalam bentuk karya seni (seni rupa), yakni Patung Tau Tau.

\section{Simbol menurut Susanne Knauth Langer (1895-1985)}

Susanne Knauth Langer adalah seorang filsuf wanita, lahir pada tanggal 20 desember 1895 di New York.Sebagai guru besar mengajar di berbagai universitas di Amerika, kemudian sebagai guru besar tetap pada Connecticut Collegesejak tahun 1945.

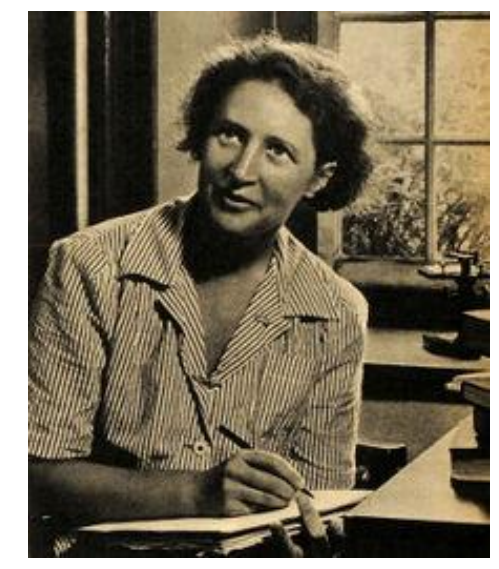

Susanne Knauth Langer (1895-1985)

Bagi Langer seni tidak terlalu asing, karena ia bertolak dari studio dimana seniman bekerja.Menurut Langer, kesenian memiliki logika yakni logika simbolis yang mampu menampilkan secara khas masalah-masalah etis. Estetika,menurutnya adalah jalan masuk ke bidang etika (Sudiarja, 1983:68-69).Sebagai seorang filsuf, Langer hadir dengan karyakaryanya yang mampu mengalihkan perhatian dengan beberapa kajian tentang simbol.Langer mulai dikenal ketika ia menerbitkan bukunya Philosophy in a New Key pada tahun 1942. Buku ini mengadakan kejuatan dalam teori mengenai simbol, terutama karena pemisahan dirinya yang tegas dari tradisi neopositivistis yang amat lazim saat itu. Kemudian, ada pula beberapa karya lainnya, sepertiAn Introduction to Symbolic Logic, 
terbit tahun 1937;Feeling and Form, terbit tahun 1953;Problems of Art, terbit tahun 1957; Philosophical Sketches, terbit tahun 1962; danMind: an Essay on Human Feeling, terbit tahun 1967. Kemudian, pada tanggal 17 juli 1985, Langer meninggal dunia di Old Lyme, Connecticut, Amerika.

Mengenai simbol, Susanne Knauth Langer (1895-1985) berbeda dengan Imanuel Kant (1724-1804).Kant memandang simbol adalah hasil refleksi, tindakan sengaja akal menunjuk ke yang transenden.Sementara, menurut Langer simbolisasi primordial tidak tersadari.Langer memandang simbolisasi sebagai penyatuan dua hal luluh menjadi satu pada saat paling awal gerak batin manusia.Semua macam simbolisasi yang terjadi kemudian didahului oleh simbolisasi primordial (Triguna, 2000:18).

Pemikiran Langer yang mendapat inspirasi dari kenyataan bahwa penangkapan manusiawi lebih bersifat mentransformasikan, yakni kemampuan mengungkapkan dalam bermacam-macam bentuk sehingga tidak perlu anggapan adanya suatu "roh manusiawi yang transenden".Ini kemudian membentuk dasar pemikiran Langer, bahwa transformasi simbolik merupakan aktivitas alamiah, dimana suatu kejadian bentuk tinggi reaksi syarafsyaraf yang khas manusiawi. Bagi Langer, simbolisasi adalah keduanya, yaitu suatu tujuan, dan suatu alat.Langer menyejajarkan perbuatan simbol sebagai kegiatan primer, dengan demikian sampailah pada pemahaman bahwa simbolisasi adalah tindakan esensial pikiran (mind) dan mind mencakup lebih daripada sesuatu yang disebut akal peikiran (Through).Kemudian, Langer mengajukan prinsip simbolisasi sebagi prinsip yang lebih kuat sehingga ide-ide menjadi terbentuk (Triguna, 2000:18-20).

Susanne Knauth Langerdalam bukunya yang berjudul Philosophy in a New Key (1942),menyatakan bahwa simbol tidak mewakili objeknya, tetapi wahana bagi konsep tentang objek.Membicarakan sesuatu, maka yang dibicarakan adalah konsep mengenai sesuatu itu, dan bukan sesuatu itu sendiri; dan semuanya ini tentang konsep, bukan sesuatu itu, simbol-simbol harus diartikan, sebab bilamana simbol diungkapkan, maka makna muncullah makna (Sumardjo, 2010:101). 
Langer membedakan simbol menjadi dua macam, yakni simbol diskursif dan simbol penghadiran atau yang sering disebut simbolpresentasional.Menurut langer, simbol diskursif digunakan dalam bahasa tulis dan lisan untuk berkomunikasi dengan pihak lain. Simbol diskursif adalah simbol yang cara penangkapannya mempergunakan nalar atau intelek (Saragi, 2007:9).Pada simbol diskursif, tersirat suatu struktur yang dibangun oleh unsur-unsur menurut aturan perhubungan tertentu, sehingga dengan itu dapat dipahami maknanya.Namun, menurut langer, simbol yang diskursif atau yang nalar dalam konteks neopositivisme sebetulnya sudah cukup dan tidak perlu dipersoalkan lagi (Sudiarja, 1983:71).

Sementara, mengenai simbol presentasional, dimana Langer yang memulai kriterianya dari latar belakang neopositivisme, perhatiannya tidak ditarik oleh metafisika, tetapi perhatiannya justru serta-merta ditarik pada permasalahan simbol dan ciri diskursivitas.Sebuah pertanyaan akan kemungkinan hadir suatu macam simbol lain yang pemahamannya tidak tergantung pada hukum yang mengatur perhubungan unsur-unsurnya, seperti pada simbol diskursif, melainkan pada intuisi langsung.dengan demikian, Langer merumuskan suatu simbol lain yang disebutnya "simbol presentasional", dimana simbol macam ini tidak berupa suatu konstruksi yang bisa diuraikan ke unsur-unsurnya, melainkan satu kesatuan yang bulat dan utuh, setra merupakan suatu simbol yang dapat berdiri sebagai simbol yang penuh (Sudiarja, 1983:72). Adapun cara penangkapan simbol presentasional tidak memerlukan intelek, tetapi dengan spontan ia menghadirkan apa yang dikandungnya, yang kemudian simbol inilah yang sering dijumpai dalam kreasi seni, seperti lukisan, taritarian, pahatan, patung, dst (Wibisono, 1977:147).

Menurut Langer, seni tidak dapat didekati secara sekaligus menyeluruh. Namun, meskipun ini tidak berarti bahwa masing masing kesenian mempunyai prinsip-prinsip yang berlainan satu sama lain, untuk memperoleh teori umum yang berlaku untuk semua seni dapat dilakukan dengan jalan melacak masing-masing prinsip yang berlaku untuk seni yang bersangkutan. Dengan demikian, titik-titik pertemuan dari berbagai kesenian dapat ditentukan.Dari hal -hal yang umum berlaku untuk semua kesenian, seperti prinsip kreasi seni, jenis konsepsi seni "living form" dan ekspresi (Sudiarja, 1983:73). 


\section{Patung Tau Taudi Toraja dalam Teori Simbol Susanne K. Langer}

\section{Patung Tau Tau sebagai Simbol Presentasional}

Patung Tau Tau atau oleh masyarakat suku adat Toraja menyebuntnya Ma’ Tau Tau, bersangkutan dengan penyembahan terhadap arwah nenek moyang.Oleh karena itu, Patung Tau-Tau tersebut harus dihormati, disembah dan diratapi.Patung Tau Tau juga dipakai sebagai penghubung antara manusia dan arwah orang yang telah meninggal.

Patung Tаи Tau sebagai presentasional atau penghadir, harus dipahami bahwa patung ini bukan sekedar patung untuk patung, tetapi terdapat makna yang lebih luasdan mendalam dibalik patung itu sendiri.Di sini, kekuatan dan kedahsyatan alam, roh para leluhur atau nenek moyang, yang tidak dimengerti itu digambarkan menjadi sebuah material yang meniru tangkapan logika manusia atau masyarakat Toraja itu sendiri. Logika sederhana ini, mengaktualisasikan yang transenden menjadi imanen, yang kemudian inilah yang dimaksud Langer sebagai pemahaman simbol dengan intuisi langsung(Sudiarja, 1983:72), dimana pemahaman simbol dilakukan secara utuh, menyeluruh, tidak parsial dari unsur-unsurnya yang lebih kecil.

Sebagaimana, simbol presentasional merupakan simbol yang cara penangkapan tidak memerlukan intelek, tetapi dengan spontan ia menghadirkan apa yang dikandungnya, serta berdiri sendiri sebagai simbol yang penuh,bukan sebagai suatu konstruksi, bukan pula suatu unsur dari suatu konstruksi atau susunan (Sudiarja, 1983:72), maka makna Patung Tau Tau sebagai simbol ditangkap dalam arti keseluruhan, yakni melalui hubungan antara elemenelemen simbol dalam struktur keseluruhan. Patung Tau Tau di Toraja dengan berbagai pernak pernik yang melekat pada patung, telapak tangan menghadap keatas, serta bentuknya yang kaku belum mengandung arti jika tidak dipahami bentuk secara keseluruhan. 


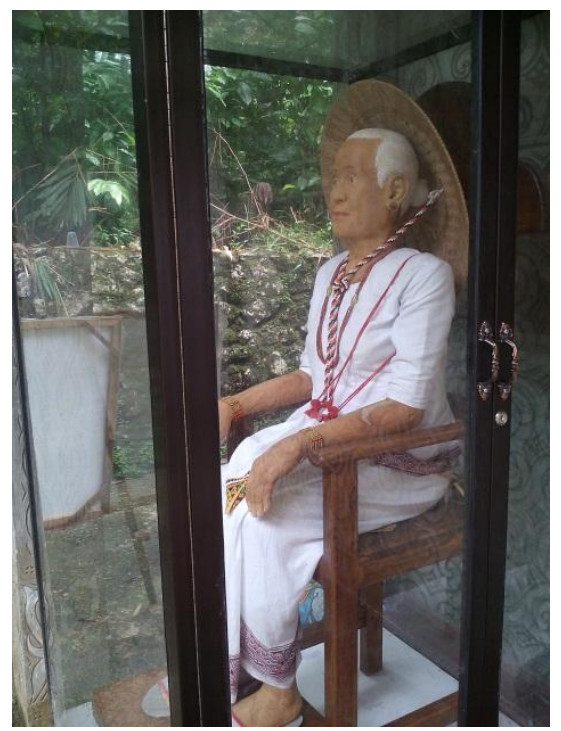

Patung Tau Tau sebagai Simbol Presentasional

Patung Tau Tau harus dipandang sebagai suatu simbol yang penuh dan utuh, serta dalam bentuk secara keseluruhan, walaupun unsu-unsur pembentuk Patung Tau Tau itu sendiri terdiri dari berbagai simbol yang sifatnya lebih khusus. Pemahamannya bukan berdasarkan unsur-unsurnya, melainkan kesatuan dari unsur-unsur itu yang kemudian membentuk simbol yang lebih baru sifatnya, yakni simbol dalam bentuk secara keseluruhan.Di sinilah peran intuisi langsung menjadi urgen.Demikian, karena sesuai dengan pemaknaan Langer tentang simbol patung primitif, yakni memiliki kekhasan sendiri, seni patung primitif adalah media ritual pada zamannya (Saragi, 2007:16).Ini sangat berkaitan dengan Patung Tau Tau di Toraja, sebagaimana Patung Tau Tau merupakan salah satu ritual kematian yang oleh masyarakat suku adat toraja disebutnya Aluk Rambu Solo'.

Makna patung primitifdibentuk oleh kesatuan unsur intrinsik dan eksintriknya (Saragi, 2007:15).Mitos dan folklore sebagai bentuk eksintrik berhasil membentuk pengertian makna patung itu sendiri.Demikian pula dengan Patung Tau Tau yang maknanya sebagai simbol, bersumber dari mitos yang terkontaminasi atau memasuki sarafsaraf pikiran masyarakat suku adat Toraja.Sebagaimana Mircea Eliade, bahwa mitos merupakan usaha manusia religius arkhais untuk melukiskan lintasan yang supra-natural 
kedalam dunia (Susanto, 1987:71). Simbol dan mitos sangat erat kaitannya, sebab mitos merupakan simbolisai ketegangan hidup manusia dalam pergumulannya untuk mengartikan dunia dan dirinya yang berupa misteri yang gaib.Dengan demikian, Patung Tau Tau di Toraja merupakan simbol hadirnya suatu mitos (mitos dalam kepercayaan suku adat Toraja/Aluk Todolo).

\section{Patung Tau Tau sebagai Virtual Space}

Patung merupakan suatu bentuk fisis tentang sesuatu yang metafisis.Patung adalah vitrtual space (ruang yang sungguh) dari kekuatan atua daya energy yang metafisis (Saragi, 2007:16).Patung menjadi bentuk nyata dari ide-ide yang semu, yang mampu menjelaskan sesuatu "yang ada belum terpahami” dengan simbol-simbol.Sebagaimana, Nelson Goodman (1906-1998) memandang patung bukan dari sisi representasi atau peniruan, melainkan dari sudut ekspresi dan invensi (Wibowo, 2015:115).Pematung umumnya tidaklah sekedar mengkopi realitas, melainkan menciptakan simbol-simbol baru yang khas.Demikian, sesuai dengan pandangan Langer, bahwa seni itu tidak mengulang alam. Seni sungguh-sungguh menghasilkan sesuatu yang lain sama-sekali dengan realitas alamiah (Sudiarja, 1983:75). Di sini, Langer berbeda pandanganAristoteles (384-322 SM),dan menolak teorinya yang mengatakan bahwa seni merupakan peniruan (memesis).

Demikian "virtual space” (ruang yang sungguh) telah dijelaskan bahwa virtual space merupakan ilusi primer dalam seni plastis (lukisan, patung, dan arsitektur), dalam hal ini Patung Tau Tau juga termasuk di dalamnya sebagai karya seni yang tercipta dari dasar kreasi seni, yakni ilusi primer (primary illusion).Jadi, virtual space merupakan jembatan simbol dari yang tidak terpahami menjadi terpahami.Oleh karena itu, Patung Tau Tau dalam kepercayaan Aluk Todolo menjelaskan adanya konsepsi tatanan dan tuntunan kehidupan dalam kosmos, sehingga misteri-misteri kedahsyatan dalam kosmos dapat terungkap dalam bentuk simbol-simbol seni. 


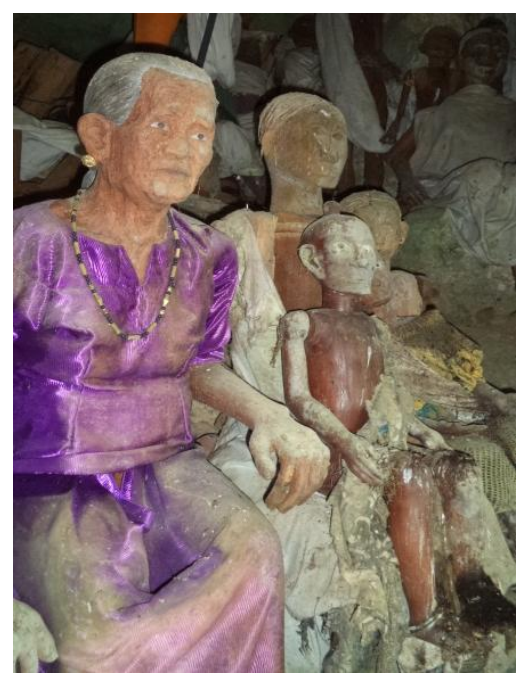

\section{Patung Tau Tau sebagai Virtual Space}

Patung Tиаи Таи merupakanvirtual space atau gambaran dari mitos-mitos yang menyebar dalam kehidupan masyarakat suku adat Toraja. Konsepsi mitos tentang kehidupan lain setelah kehidupan di dunia nyata, yang telah merasuk dalam keyakinan masyarakat suku adat Toraja diwujudkan dalam bentuk patung. Eksistensinya jelas nyata dapat dilihat dan diraba, namun kekuatan dan kemagisan cerita mitos tentang arwah para leluhur atau nenek moyang yang hidup tersebar dalam masyarakat Toraja, melainkan pada tanggapan dan sangkaan dalam pikiran masyarakat pendukungnya.Patung Tau Tau hanyalah virtual space (ruang yang sungguh) dari ungkapan perasaan atas konsepsikonsepsi mitos itu.

Eksistensi "virtual" bukanlah sesuatu yang tidak nyata dimana manusia menghadapinya, melainkan suatu penyajian peristiwa yang bersifat subjektif dalam simbol yang bersifat objektif.Setiap karya seni merupakan sebuah citra, baik itu berupa tari, patung, lukisan, musik, ataupun kasrya sastra (Saragi, 2007:17).Ini merupakan pertunjukan atau presentasi objektif dari realitas subjektif oleh pancaran dari alam batin penciptanya, yang melambangkan sesuatu dari kehidupan batiniahnya.Suatu fenomena yang murni, yang bersifat objektif, tampak diisi dengan perasaan karena bentuknya yang berupa ungkapan yang sangat mendasar dari perasaan.Bagaimanapun bentuknya, yang pasti setiap karya seni merupakan suatu objektivikasi kehidupan subjektif.Dengan demikian, Patung Tau 
Tausebagai karya seni, merupakan gambaran virtual atau gambaran sebenarnya dari apa yang menjadi konsepsi-konsepsi tentang mitos-mitos kematian yang diketahui penciptanya, dalam hal ini masyarakat suku adat Toraja itu sendiri.

\section{Patung Tau Tau sebagai Simbol Ekspresi dan Bentuk Hidup (Living Form)}

Pada masa animisme, patung diciptakan sebagai manifestasi hubungan antara manusia, alam lingkungannya, dan alam semesta.makna dan fungsinya sangat berkaitan erat dengan upacara keagamaan dan biasanya dianggap sebagai perwujudan nenek moyang atau wujud kehadiran dimensi alam lain (Wibowo, 2015:113).Patung primitif misalnya, dimana dalam kehidupan masyarakat primitif, manusia dengan dorongan nalurinya selalu ingin menangkap fenomena dan objek-objek alam.Patung primitif sebagaimana bahasa adalah bentuk simbol pemikiran yang rasional.Hal ini dapat ditemukan dalam karya-karya yang dibuat oleh manusia primitif pada zamannya, seperti coretan, gambar, ukiran-ukiran batu dan kayu, serta berbagai macam peninggalan-peninggalan masyarakat primitif dengan sifat dan karakter yang sama. Demikian, oleh karena ketika menyadari apa yang dilakukan membutyanya terperanjat dan ketakutan meliahat binatang, manusia, dan fenomena alam yang kemudian ditangkapnya dalam bentuk benda-benda dan gambar.Sebagai masyarakat

primitif, dunia yang mereka pahami adalah dunia dalam batas-batas kekuatan mitis, oleh Van Peursen dikataknnya manusia dalam tahap pemikiran mitis, yakni sikap serba terkurung atau imanensi (Soedarso, 2006:31). Oleh karena itu, segala sesuatu yang dilakukan tentunya masuk akal, sebab apa yang mereka lakukan merupakan logika mereka dalam memahami alam.

Patung Таи Tau sebagai simbol ekspresi dan bentuk hidup (living form), sebagaimana Patung Tau Tau merupakan replika orang Toraja yang meninggal dunia.Dalam kepercayaan suku adat Toraja Tau Tau diberlakukan karena orang-orang mempercayai bahwa patung tersebut memiliki jiwa dari jiwa orang yang telah meninggal (Tau Tau adalah living dead).Patung Tau Tau sebagai bentuk ekspresi, bukan berarti bahwa ini semata-mata pelepasan liar.Dengan demikian, harus dipahami dan dicitrakan secara menyeluruh.Patung Таи Таи merupakan salah satu bahasa ungkapan perasaan dan buah fikiran orang yang ditinggalkan, yang kemudian menjadi bentuk simbol dalam penampilan yang lain daripada 
apa yang dihasilkannya. Apa yang diungkapkan dalam Patung Tau Tau, tidak lain adalah cita tentang suatu perasaan atau ungkapan rasa dalam pengertian yang luas. Oleh sebab itu, makna yang terkandung pada elemen-elemen Patung Tau Tau bukanlah makna yang sebenarnya, melainkan pada bentuk ekspresinyalah ditemukan makna yang sesungguhnya.

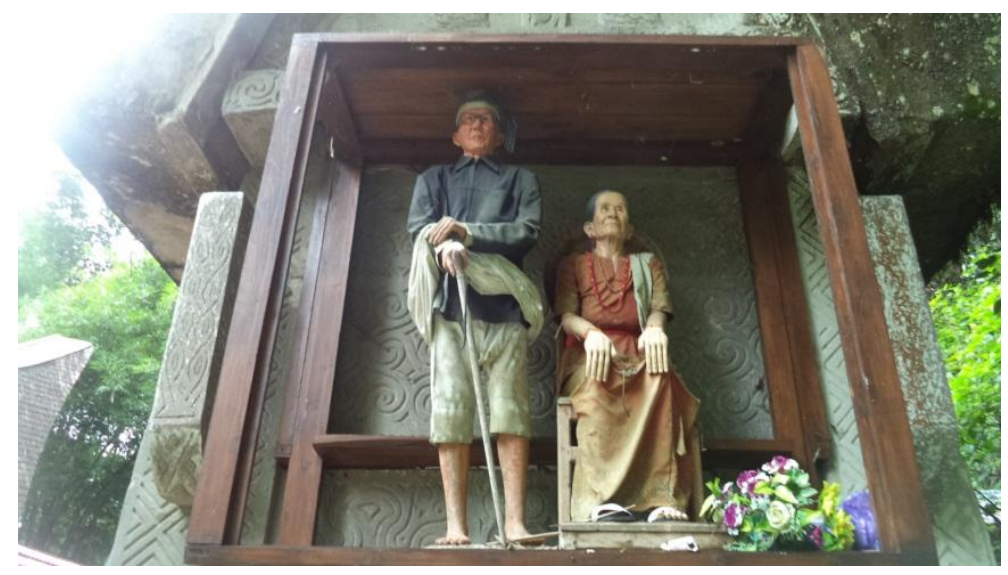

Patung Tau Tau sebagai Simbol Ekspresi dan Living Form

Konsepsi seni sebagai kreasi bentuk-bentuk ekspresi yang menyampaikan citra perasaan, yang kemudian Langer menyebutnya "kehidupan batiniah", "realitas subjektif", dan "kesadaran" (Saragi, 2007:13).Dalam hal ini, Eksistensi seni dapat dicitrakan.Patung Tau Tau adalah salah satu contohnya, dimana eksistensi subjektif dari orang yang ditinggalkan diciptakan dalam bentuk patung (replika almarhum) sehingga Patung Tau Tau menjadi simbol-simbol pengalaman. Demikian, oleh karena sesuai dengan apa yang dikatakan langer, bahwa realitas yang diangkat ke dalam simbol seni bukanlah realitas objektif, melainkan realitas subjektif, sehingga bentuk atau forma simbolis yang dihasilkan mempunyai ciri khas. Forma simbolis inilah yang disebut Langer sebagai forma yang hidup "living form” (Sudiarja, 1983:78).Prinsip "ke-hidup-an" dari forma simbolis pada seni, tentunya berlaku untuk semua kesenian. Tebal tipinsnya cat, jenis warna, keras lembutnya bunyi, akan menampilkan "kehidupan" pada seni.

Adapun Patung Tau Tau di Toraja, yang juga merupakan salah satu karya seni primitif (patung primitif), bukanlah merupakan bentuk visual semata, melainkan mampu menghadirkan bentuk hidup "living form" dari konstruksi berbagai elemen-elemen yang 
membangunnya. Hal ini dapat dilihat dari proses terciptanya Patung Tau Tau yang bersumber dari emosi penggabungan berbagai elemen, seperti garis, bidang, warna, bentuk, yang terjadi dari ketegangan hidup serta resolusinya yang menyentuh, yang kemudian dari konstruksi elemen-elemen inilah yang membuat bentuk hidup "living form" sehingga Patung Tаu Tau bukan hanya dilihat secara datar, melainkan muncul pesona, ketakjuban yang sulit untuk diungkapkan.Di sisni, emosi menjadi penting, sebab menurut Langer, Feeling atau emotionmerupakan faktor penting lahirnya suatu pengalaman, serta menjadi faktor yang amat menentukan timbulnya simbol pada manusia (Wibisono, 1977:146).

\section{Patung Tau Tau sebagai Simbol Seni}

Simbol seni sebagaimana, bukanlah hanya suatu susunan yang mempunyai makna, bukan pula suatu struktur atau konstruksi, akan tetapi simbol seni merupakan suatu kreasi yang utuh, penuh, dan berdiri sendiri sebagai satu kesatuan simbol. Pemahaman secara umum, bahwa sesuatu itu bermakna ketika di dalamnya terjalin suatu ketersusunan atau keteraturan.Namun, simbol seni berbeda dengan hal itu.Simbol seni bukanlah suatu susunan, jadi tidak dapat dikatakan teratur atau tidak teratur. Demikian, Langer menerangkan bahwa simbol seni adalah satu dan utuh, karena itu ia tidak menyampaikan "makna" (meaning) untuk "dimengerti", melainkan suatu "pesan" (import) untuk “diresapkan (Sudiarja, 1983:77). Manusia hanya dapat mengerti atau tidak mengerti terhadap "makna", tetapi terhadap "pesan" manusia dapat tersentuh secara lemah dan intensif, sehingga dikatakan bahwa terdapat elastisitas yang luas terhadap peresapan "pesan” seni itu.Demikian halnya Patung Tau Tau di Toraja sebagai simbol seni. Patung Таи Таи merupakan simbol seni yang satu dan utuh, karena ia tidak menyampaikan “makna”, melainkan memberi "pesan" yang perlu untuk diresapi oleh masyarakat. 


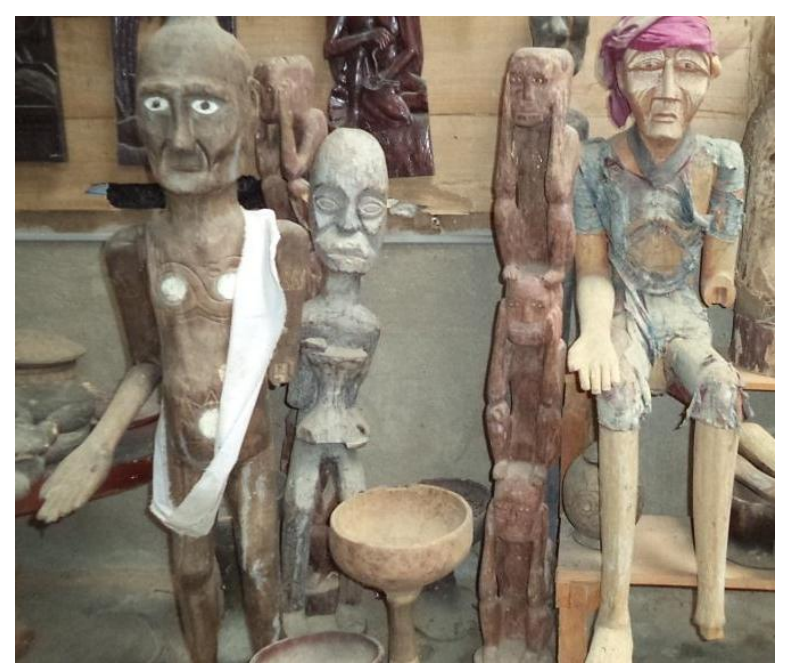

Patung Tau Tau sebagai Simbol Seni

Selain itu, Patung Tau Tau sebagai simbol seni, sebagaimana simbol seni merupakan suatu abstraksi yang total dan menyeluruh yang kemudian menjadi satu kesatuan simbol. Ini berarti dalam simbol seni, abstraksi merupakan suatu bentuk perkembangan yang rampung (terminal). Patung Tau Tau bukan lagi merupakan tahapan simbolisasi yang belum rampung atau masih menantikan penyempurnaan dalam bentuk simbol yang lain. Patung Tau Tau telah menjadi simbol seni yang utuh dan penuh. Dikatakan demikian, karena Patung Tau Tau di Toraja adalah bentuk atau wujud dari cerita "mitos" yang turuntemurun, yang kemudian menjadi suatu kepercayaan masyarakat suku adat Toraja. Cerita mitos inilah yang dimaksud sebagai simbolisasi yang belum rampung dan masih membutuhkan penyempurnaan.Oleh Langer, dikatakannya bahwa Mitos "dalam agama primitif” adalah simbolisasi yang belum selesai. Sama halnya di Toraja. Di Toraja, mitos itu kemudian disempurnakan, dirampungkan atau diselesaikan dalam bentuk patung, yakni Patung Tau Tau.

\section{KESIMPULAN}

Berdasarkan uraian di atas mengenai Patung Tau Tau di Toraja dalam teori simbol Susanne Knauth Langer, maka dapat ditarik kesimpulan, bahwa Patung Tau Tau sebagai simbol presetasional, sebagaimana ia bersumber dari mitos. Makna Patung Tau Tau sebagai simbol ditangkap dalam arti keseluruhan, yakni melalui hubungan antara elemen-elemen 
simbol dalam struktur keseluruhan, walaupun unsu-unsur pembentuknya terdiri dari berbagai simbol yang sifatnya lebih khusus.Patung Tau Tau di Toraja merupakan simbol hadirnya suatu mitos (mitos dalam kepercayaan suku adat Toraja/Aluk Todolo).

Patung Tau Tau di Toraja sebagai virtual space (ruang yang sungguh).Demikian, Patung Таи Tаu sebgai gambaran dari mitos-mitos yang menyebar dalam kehidupan masyarakat suku adat Toraja. Konsepsi mitos tentang kehidupan lain setelah kehidupan di dunia nyata, yang telah merasuk dalam setiap saraf-saraf masyarakat suku adat Toraja diwujudkan dalam bentuk patung. Patung Tau Tau hanyalah virtual space dari ungkapan perasaan atas konsepsi-konsepsi mitos itu. Dengan demikian, Patung Tau Tau sebagai karya seni, merupakan gambaran "virtual" atau gambaran sebenarnya dari apa yang menjadi konsepsi-konsepsi tentang mitos-mitos "kematian" pada masyarakat suku adat Toraja itu sendiri.

Kemudian, Patung Tau Tau sebagai simbol ekspresi dan bentuk hidup (living form), oleh karena Patung Таи Tаи merupakan ekspresi atau bahasa ungkapan perasaan dan buah fikiran orang yang ditinggalkan, yang kemudian menjadi bentuk simbol dalam penampilan yang lain daripada apa yang dihasilkannya. Apa yang diungkapkan dalam Patung Tau Tau, tidak lain adalah cita tentang suatu perasaan atau ungkapan rasa dalam pengertian yang luas. Oleh sebab itu, makna sesungguhnya yang terkandung pada elemen-elemen Patung Tau Tauditemukan pada bentuk ekspresinya.Adapun Patung Tau Tau di Toraja, yang juga merupakan salah satu karya seni primitif (patung primitif), bukanlah merupakan bentuk visual semata, melainkan mampu menghadirkan bentuk hidup "living form" dari konstruksi berbagai elemen-elemen yang membangunnya. Konstruksi elemen-elemen inilah yang membuat bentuk hidup "living form" sehingga Patung Tau Tau bukan hanya dilihat secara datar, melainkan muncul pesona, ketakjuban yang sulit untuk diungkapkan.

Selanjutnya, Patung Tau Tau sebagai simbol seni yang satu dan utuh, karena ia tidak menyampaikan "makna", melainkan memberi "pesan" yang perlu untuk diresapi oleh masyarakat. Patung Tau Tau bukan lagi merupakan tahapan simbolisasi yang belum rampung atau masih menantikan penyempurnaan dalam bentuk simbol yang lain. Namun, 
Patung Tau Tau telah menjadi simbol seni yang utuh dan penuh. Demikian, karena Patung Tau Tau di Toraja adalah bentuk atau wujud dari cerita "mitos" yang turun-temurun, yang kemudian menjadi suatu kepercayaan masyarakat suku adat Toraja.

\section{DAFTAR PUSTAKA}

Bakker, Anton. 1985. Manusia dan Simbol. Dalam Soerjanto Poespowardojo dan K. Bertens. Sekitar Manusia. Jakarta: Gramedia.

Bahari, Nooryan. 2014. Kritik Seni: Wacana, Apresiasi dan Kreasi. Yogyakarta: Pustaka Pelajar.

Cassirer, Ernest. 1990. Manusia dan Kebudayaan: Sebuah Esay Tentang Manusia. Diterjemahkan oleh Alois A. Nugroho. Jakarta: Gramedia.

Daeng, Hans. J. 2000. Manusia Kebudayaan dan Lingkungan. Yogyakarta: Pustaka Pelajar.

Hadi, Y. Sumandiyo. 2006. Seni dan Ritual Keagamaan. Yogyakarta: Penerbit Buku PUSTAKA.

Langer, Susanne Knauth. 1957. Problems of Art: Ten Philosophical Lectures,(edition 6). New York: Charles Scribner Sons.

. 1953. Feeling and Form. New York: Charles Scribner Sons.

. 1976. Philosophy in a New Key: A Study in the Symbolism of Reason, Rite and Art,(third edition).Cambridge, Massachusetts: Harvard Univercity Perss.

Peursen, Van. 1993. Strategi Kebudayaan, (cetakan ke 4). Yogyakarta: Kanisius.

Read, Herbert. 1970. Art and Society. New York: Shocken Book.

Rohidi, Tjetjep Rohendi. 2000. Kesenian dalam Pendekatan Kebudayaan. Bandung: STISI Perss.

Said, Abdul Azis. 2004. Toraja: Simbolisme Unsur visual Rumah Tradisional dan Perubahan Aplikasinya pada Desain Modern. Yogyakarta: Ombak.

Saragi, Daulat. 2007. "Dimensi Simbolik Patung Primitif Batak: Kajian Menurut Konsep Estetika Susanne Knauth Langer”. Ringkasan Disertasi (Tidat diterbitkan). UGM Yogyakarta.

Sitonda, Mohammad Natsir. 2007. Toraja: Warisan Duni. Makassar:Pustaka Refleksi.

Soedarso Sp. 2006. Trilogi Seni: Penciptaan, Eksistensi, dan Kegunaan Seni. Yogyakarta: BP ISI Yogyakarta.

Subiyantoro, Slamet. 2010. Antropologi Seni Rupa: Teori, Metode, dan Contoh Telaah Analitis. Surakarta: LPP UNS dan UNS Press. 
Sudiarja, A., "Susanne K. Langer: Pendekatan Baru dalam Estetika".dalam M. Sastrapratedja (ed.). 1983.Manusia Multidimensional: Sebuah Renungan Filsafat. Jakarta: PT. Gramedia.hal. 68-81.

Sumardjo, Jakob. 2010. Estetika Paradoks (Edisi Revisi). Bandung: Sunan Ambu STSI Press.

Susanto, P.S. Harry, 1987.Mitos Menurut Pemikiran Mircea Eliade. Yogyakarta: Kanisius.

Triguna, Ida Bgus Gde Yudha. 2000. Teori tentang Simbol. Denpasar Timur: Widya Dharma.

Uhi, Jannes Alexander. 2016. Filsafat Kebudayaan: Konstruksi Pemikiran Cornelis Anthonie van Peursen dan Catatan Reflektifnya. Yogyakarta: Pustaka Pelajar.

Wibisono, I. Wibowo., "Simbol Menurut Susanne K. Langer, dalam F. Danuwinata (ed.). 1977. Dari Sudut-Sudut Filsafat: Sebuah Bunga Rampai. Yogyakarta: Kanisius. hal. 142-153.

Wibowo. Pius Prio., "Patung dan Perkembangan Mutakhirnya". dalam Bambang Sugiharto (ed.). 2015. Untuk Apa Seni?.Bandung: Pustaka Matahari.

\section{Webtografi}

http://wandaseptianibulo.blogspot.co.id/2011/05/ritual-kematian-dan-kepercayaan.html http://www.pengetahuan-oemum.com/2014/12/patung-tau-tau.html 